\title{
Mandibular coronoid process hyperplasia: a case report
}

\author{
Meire Cristiane Alves Tolentino(1) \\ Jocasta Santos Assis ${ }^{(2)}$ \\ Claudia Assunção e Alves Cardoso(2) \\ Flávio Ricardo Manzi(2)
}

(1) Centro de Estudos OdontológicosInstituto de Previdência dos Servidores do Estado de Minas Gerais, Belo Horizonte, Minas Gerais, Brasil.

(2) Pontifícia Universidade Católica de Minas Gerais, Belo Horizonte, Minas Gerais, Brasil.

Conflict of interests: Nonexistent

\section{(c) (i)}

Received on: August 3, 2017 Accepted on: March 19, 2018

Mailing address:

Flávio Ricardo Manzi

Av. Dom José Gaspar, 500- Prédio 46 ,

Bairro Coração Eucarístico

CEP 30535-901- Belo Horizonte, Minas

Gerais, Brasil

E-mail: manzi@pucminas.br

\section{ABSTRACT}

Coronoid Process Hyperplasia is a rare condition characterized by the increase in size of a histologically normal bone. It can be confused with Temporomandibular Joint Dysfunction, due to the presence of major signs/symptoms, including the limitation of mouth opening, pain, and facial asymmetry. Although several theories have been proposed, the etiology remains unknown. The recommended treatment is mandibular coronoidectomy. In the present study, the importance of computed tomography to reach the proper diagnosis and the surgical treatment plan is demonstrated.

Keywords: Hyperplasia; Temporomandibular Joint Dysfunction Syndrome; Tomography 


\section{INTRODUCTION}

Mandibular coronoid process is an anterior eminence of the mandibular ramus, where the temporal muscle is connected. The temporal muscle is a muscle of mastication, covered by very dense fascia, whose fibers are laid out in three directions (anterior, medium, and posterior) - in a fan shape. This process originates on the temporal fossa floor and is connected to the medial face of the mandibular coronoid process, from the temporal crest to the surroundings of the retromolar trigone. The temporal muscle is considered to be a muscle more related to movement than to masticatory force and is responsible for mandible elevation and retraction ${ }^{1-3}$

Hyperplasia of the mandibular coronoid process (HCP) is a rare condition, which is characterized by cell growth of a histologically normal bone, and whose symptoms increase gradually ${ }^{4}$. The most frequently reported symptoms are pain and limited mouth opening $^{5}$. Elongated coronoid processes affect the medial surfaces of zygomatic arches at the mouth opening, which limit mandible movement and lead to trismus ${ }^{6}$. The etiology of HCP is still unknown, but it has been associated with endocrine conditions, temporal muscle hyperactivity, traumas, articular disc displacement without reduction, and genetic heritage ${ }^{7}$.

The main dysfunctions mistaken for HCP are Jacob's Disease and Temporomandibular Joint Dysfunction (TMD). The first is characterized by the joint between the coronoid process and the jawbone, accompanied by cartilaginous structures and the formation of a synovial capsule $^{8}$. The latter is characterized by any alterations that affect masticatory muscles, the temporomandibular joint (TMJ), and adjacent structures ${ }^{9}$.

HCP usually begins during the second decade of life, but the majority of patients only seek the counsel of a specialized professional after several years, when the anomaly begins to affect their quality of life. Furthermore, its symptoms are common to several other conditions, such as TMD, trismus, and other tumoral alterations of the coronoid process. An HCP diagnosis is seldom taken into consideration ${ }^{10}$. Therefore, the importance of complementary image exams to assist in reaching a correct diagnosis is evident, particularly in the relation between the abnormal coronoid process and the zygomatic arch, given that it is the most frequent case of mandibular hypomobility. HCP more commonly affects males, and it may be unilateral or bilateral ${ }^{10}$. In unilateral cases, the most frequently reported sign is facial asymmetry. The treatment of choice is the total or partial removal of the affected coronoid process(es) on the zygomatic arch through plastic surgery, if required. In addition, postoperative physical therapy is recommended after surgery ${ }^{9-14}$. Physical therapy is very important to obtain good results after the coronoidectomy and includes several therapeutic techniques involving spatula, wedge and the TheraBite Jaw Motion Rehabilitation System ${ }^{15}$.

Diagnosing HCP is quite difficult due to the similarities between its signs and symptoms and other disorders or conditions. Therefore, this work, through a case report and literature review, intended to demonstrate the diagnostic accuracy obtained with computed tomography (CT) scans, as well as their relevance for surgical treatment and planning, which enable an early diagnosis and minimize possible complications for the patient.

\section{CASE REPORT}

The present project was approved by the Research Ethics Committee at the Minas Gerais Pontifícia Universidade Católica, generating the report number: 2.082.506 and the CAAE protocol number: 67203717.2 .0000 .5137$.

A female patient, L.S.M., light-skinned black, 14 years of age, sought medical care at a Radiology Clinic to undergo a CT scan of the TMJ. The scan had been requested by a dentist to complement the diagnosis of TMD. In the visual exam, no facial asymmetry was detected. The patient reported a history of gradual increase in pain and limited mouth opening.

After completion of the CT scan, no TMJ alterations were found, but mandibular coronoid process hyperplasia on the right side towards the anterior and lateral sides could be identified. Hyperplasia caused the zygomatic arch and the zygomatic bone on the right side to expand and become thinner (Figures 1 to 5). 

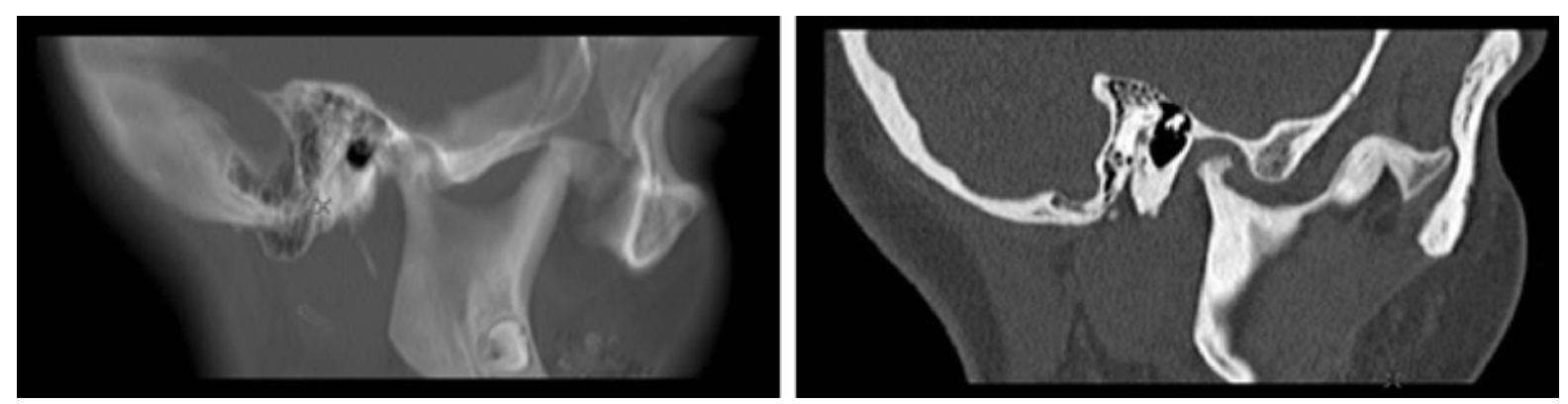

Figure 1. Temporomandibular Joint (TMJ) Computed Tomography (CT) scans on the right-mouth closed, showing hyperplasia of the coronoid process

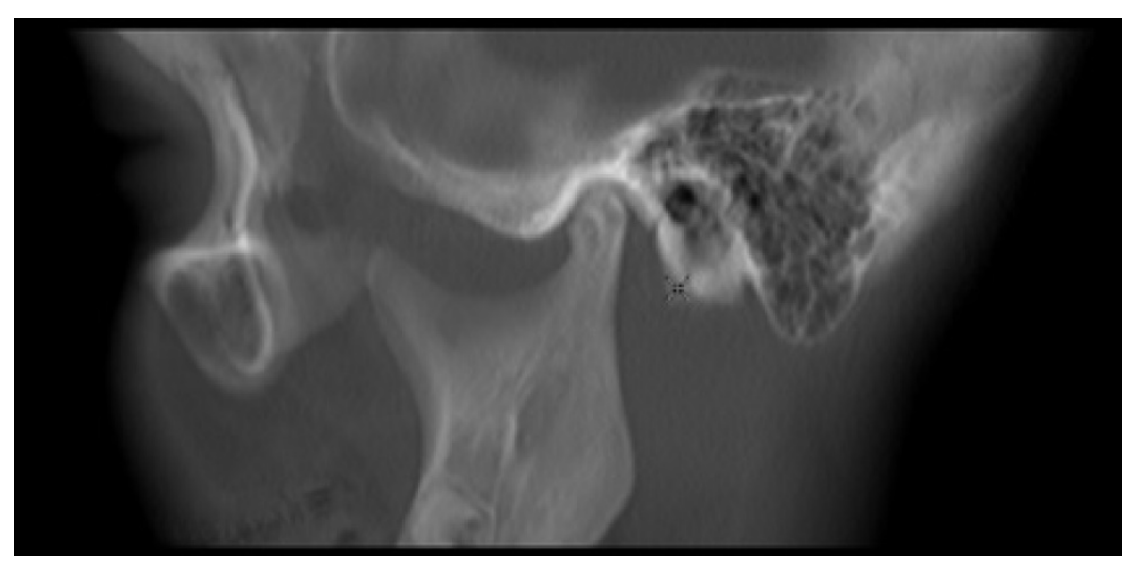

Figure 2. Temporomandibular Joint (TMJ) tomography of the left side-closed mouth, showing the normal coronoid process
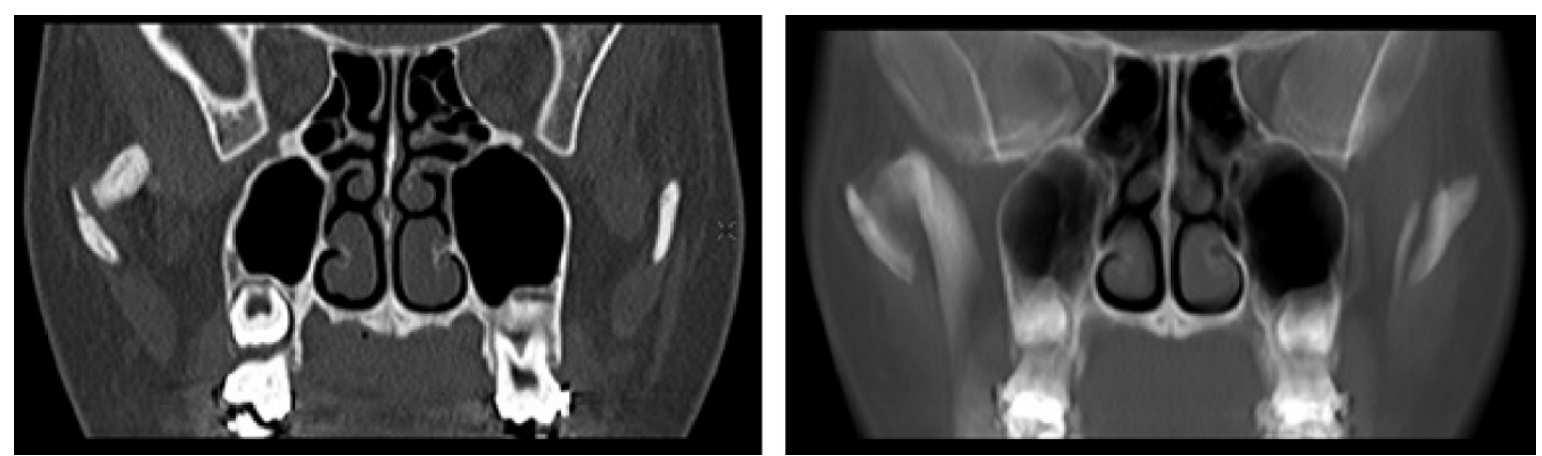

Figure 3. Coronal cuts showing unilateral hyperplasia of the coronoid process of the jaw
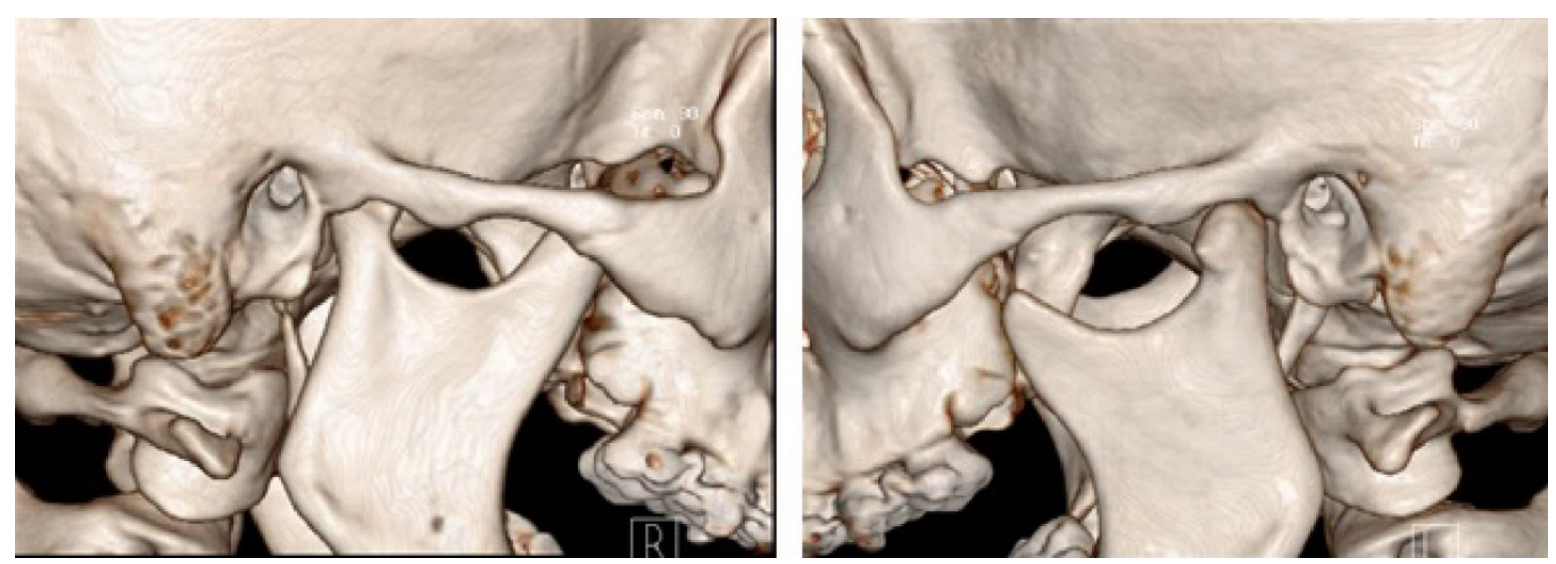

Figure 4. Three-dimensional computed tomography of the right and left sides 

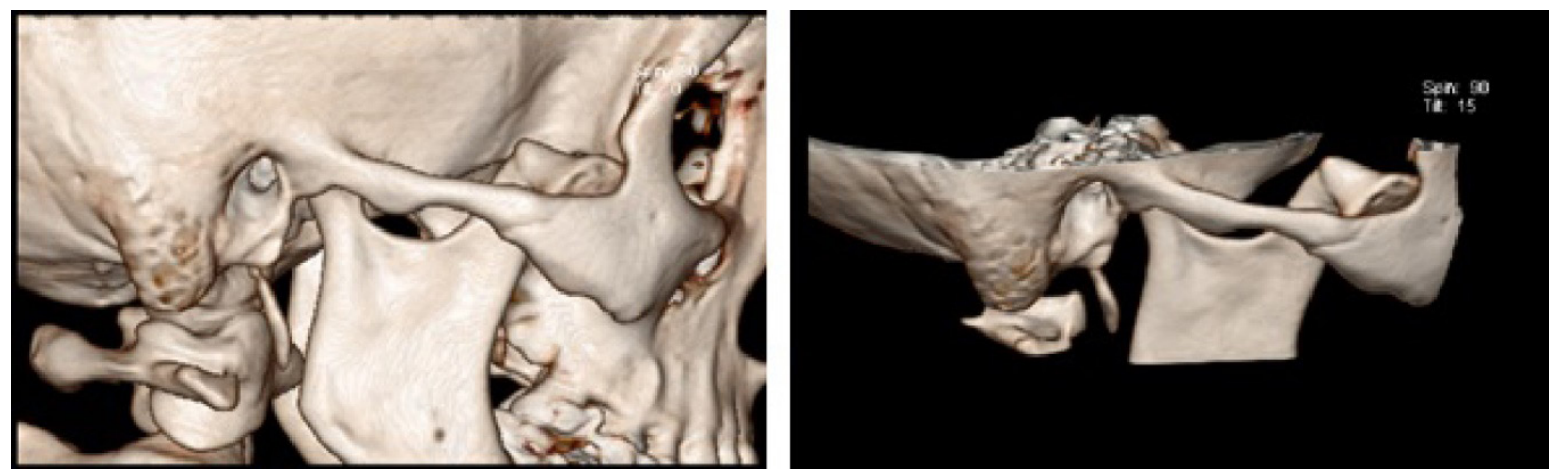

Figure 5. Three-dimensional computed tomography showing the non-anatomical contact of the coronoid process with zygomatic arch

\section{RESULTS}

After having completed the diagnosis, associated with the patient's complaint, the patient was referred to the oral and maxillofacial surgeon, who, then, performed the plastic surgery procedure on the hyperplastic coronoid process. After surgery, the patient was instructed to seek speech therapy for functional rehabilitation.

\section{DISCUSSION}

$\mathrm{HCP}$ is characterized by the growth of mature bone tissue, with no consensual casuistry. Furthermore, because the patient exhibited signs and symptoms that are common to several diseases, a simple clinical assessment is not sufficient for an appropriate diagnosis, considering that the majority of professionals are unable to identify such an alteration ${ }^{10,16}$.

HCP is a rare condition and, since the first case described by Langenbeck in $1853,{ }^{11}$ few new cases have been reported in the literature. Moreover, because its symptoms are similar to those of TMD, it is often incorrectly diagnosed. Therefore, the CT scan is clearly an exam capable of reaching the proper diagnosis and of evaluating size, shape, and relation between the coronoid process and the zygomatic arch, which is mostly used to determine the correct surgical treatment ${ }^{10,16-18}$. Similarly to what happened in the case reported above, in which the dentist suspected TMD, through a CT scan, it was possible to establish an accurate diagnosis and relation between the coronoid process and adjacent structures, mainly for the subsequent surgical procedure.

Several theories have been suggested to explain the etiology of $\mathrm{HCP}^{7,10,19,20}$, but these are not always identified. This fact is also demonstrated in the case in question, in which the etiology could not be fully clarified. It was only possible to identify that the process embedded itself slowly and gradually, which is in agreement with prior case studies ${ }^{16,21,22}$.

Rowe $(1963)^{23}$ defends the hypothesis that hormonal disorders that take place during adolescence may be related to the etiology of HCP; however, there is no biological evidence of such theory.

HCP is associated with a progressive and painful limitation of the mouth opening, especially in lateral and protrusion movements, which may be restricted due to the contact between the coronoid process and the zygomatic arch ${ }^{24,25}$. In most cases, the panoramic $x$-ray enables one to view the increased coronoid process. Nevertheless, CT scans will more precisely demonstrate the contact between both structures and will guide the surgeon during the coronoidectomy procedure, the treatment of choice for most cases reports associated with painful symptoms, followed by postoperative orofacial myofunctional therapy ${ }^{15}$.

CT with three-dimensional reconstruction is essential to differentiate coronoid process hyperplasia from other conditions, such as ankylosis, neoplastic coronoid (chondroma or osteochondroma), traumas, and thickened, but not elongated, coronoid processes.

When the patient does not exhibit favorable health conditions for surgery, it may be possible to achieve improvements in symptoms and patient satisfaction with the mere use of orofacial myofunctional therapy and oral rehabilitation, as shown in the findings from Mazzeto and Hotta ${ }^{21}$.

\section{CONCLUSION}

HCP may interfere considerably in the quality of life of patients. Therefore, a precise diagnosis is required so as to establish the appropriate treatment. A CT scan is essential in order to obtain a correct diagnosis and 
establish the relation between the zygomatic arch/ process and the increased coronoid process, mainly to plan the surgical procedure, if required.

\section{REFERENCES}

1. Oliveira MG. Manual de anatomia da cabeça e do pescoço: EDIPUCRS;2002. Pg 21. [Acesso em 15 de out de 2015]. Disponível em: https://books. google.com.br/books?id=91vyoOivVq8C\&printsec $=$ frontcover $\& \mathrm{hl}=\mathrm{pt}-\mathrm{BR} \&$ source=gbs_ge_summary $\mathrm{r} \& \mathrm{cad}=0 \# \mathrm{v}=$ onepage $\& \mathrm{q} \& \mathrm{f}=$ false.

2. Fop-Unicamp. Músculos da mastigação. [Acesso em 13 de ago de 2015]. Disponível em: http:// w2.fop.unicamp.br/dos/odonto_legal/downloads/ pos_especial/especializacao/mod3_musculos_ mastigacao.pdf.

3. Portal da educação. Músculos da mastigação. Publicado em 2 de Jan de 2013. [Acesso em 13 de ago de 2015.] Disponível em: https:// www.portaleducacao.com.br/fonoaudiologia/ artigos/25550/musculos-da-mastigacao\#!2.

4. Romano M, Porcellini G, Rossi D, Bolzoni A, Gianni $A B$, Silvestre FJ et al. Bilateral coronoid hyperplasia: a report of six cases. J Biol Regul Homeost Agents. 2017;31(2 Suppl. 1):139-45. [PMID: 28691465].

5. Ribeiro JS, Pereira RDS, Agueda C, Nunes PM, Marin C, Houchuli-Vieira E. Bilateral coronoid hyperplasia in a 43-year-old patiente treated with intraoral coronoidectomy. J. Carniofac Surg. 2017;28(4):e402-e403.

6. Kim SM, Lee JH, Kim HJ, Huh JK. Mouth opening limitation caused by coronoid hyperplasia: a report of four cases. J Korean Assoc Oral Maxillofac Surg. 2014;40(6):301-7.

7. Ilguy $M$, Kursoglu $P$, llguy $D$. Three cases of elongated mandibular coronoid process with different presentations. Iranian Journal of Radiology. 2014;11(1):e4031. doi:10.5812/iranjradiol.4031.

8. Coll-Anglada M, Acero-Sanz J, Vila-Masana I, Navarro-Cuéllar C, Ochandiano-Caycoia S, López de-Atalaya $\mathrm{J}$ et al. Jacob's disease secondary to coronoid process osteochondroma: a case report. Med Oral Patol Oral Cir Bucal. 2011;16 (6):e708-10.

9. Donnarumma MDC, Muzilli CA, Ferreira C, Nemr K. Disfunções temporomandibulares: sinais, sintomas e abordagem multidisciplinar. Rev. CEFAC. 2010;12(5):788-94.

10. Antunes RB, Goldenberg DC, Uguetto WF, Alonso N, Kowalski LP. Hipertrofia idiopática do processo coronóide mandibular: relato de caso e revisão da literatura. Rev Bras Cir Craniomaxilofac. 2010;13(4):254-8.

11. Lima PDM. Estudo da hiperplasia do processo coronóide em radiografias panorâmicas com enfoque na observação clínica [dissertação]. São Paulo (SP): Universidade de São Paulo, Faculdade de Odontologia; 2007. [Acesso em 15 out 2015]. Disponível em: http://www.teses.usp.br/teses/ disponiveis/23/23139/tde-22042008-1221.

12. Ozakaya O, Colak O, Sutcu M, Akan M. The outcome of coronoidectomy in bilateral coronoid process hyperplasia. Cranio. 2018;36(1):53-60.

13. Mohanty S, Kohli S, Dabas J, Kumar RD, Bodh $\mathrm{R}$, Yadav S. Fate of the coronoid process after coronoidotomy and its effect on the interncisal opening: a clinical and radiologic assessment. $\mathrm{J}$ Oral Maxillofac Surg. 2017;75(6):1263-73.

14. Monevska DP, Benedetti A, Popovski V, Naumovski S, Grcev A, Bozovic S et al. Mandibular movement restoration in a child with bilateral coronoid hiperplasia: a case report. J Med Sci. 2016;4(2):293-5.

15. Ferro MF, Sanromán JF, Gutiérrez JS, López AC, Sánchez AL, Pérez AE. Treatment of bilateral hyperplasia of the coronoid process of the mandible: presentation of a case and review of the literature. Med Oral Patol Oral Cir Bucal. 2008;13(9):595-8.

16. Taşkesen F, Üngör C, Dayısoylu H, Şenel FC. Trismus due to bilateral coronoid hyperplasia in an adolescent: a case report. Atatürk Üniversitesi Diş Hekimliği Fakültesi Dergisi. 2015;24(2):93-7.

17. Domingos V, Freitas CF, Fenyo-Pereira M, Raitz R. Perception of professionals in the assessment of coronoid hyperplasia by computed tomography. Acta Odontol. Latinoam. 2015;28(1):58-63.

18. Torenek K, Duman SB, Bayrakdar IS, Miloglu $O$. Clinical and radiological findings of a bilateral coronoid hyperplasia case. Eur J Dent. 2015;9(1):149-52.

19. Acharya P, Stewart A, Naini FB. Coronoid impingement syndrome: literature review and clinical management. Maxillofac Plast Reconstr Surg. 2017;39(1):11.

20. Eguia Del Valle A, Uribarri Etxebarria A, MartínezConde Llamosas R, López Vicente J, Ginestal E, Aguirre Urizar JM. Hiperplasia coronoidea bilateral. Una rara patología causante de disfunción temporomandibular. Av. Odontoestomatol. 2011;27(5):241-4. 
21. Mazzetto MO, Hotta TH. Hypertrophy of the mandibular coronoid process and structural alterations of the condyles associated with limited buccal opening: case report. Braz Dent J. 2007;18(2):171-4.

22. Ferreira AGM, Diefenbach RS, Heitz C. Limitação de abertura bucal causada por hiperplasia bilateral do processo coronóide: relato de caso. Rev Odonto Ciência - Fac. Odonto/PUCRS. 2006;21 (52):199-202.

23. Rowe NL. Bilateral developmental hyperplasia of the mandibular coronoid process: a report of two cases. Br J Oral Surg. 1963;1(2):90-104.

24. Aznar LCA, Sant'Anna GR, Juliani FAT, Zaroni WCS, Leite MF. Hiperplasia do processo coronoide: relato de caso clínico. Rev. Assoc. Paul. Cir. Dent. 2015;69(4):405-9.

25. Domingos VBTC. Avaliação da Hiperplasia do Processo coronóide por meio da tomografia computadorizada helicoidal [Tese]. São Paulo (SP): Faculdade de odontologia da Universidade de São Paulo; 2006. 